\title{
Effects of environmentally friendly degumming methods on some surface properties, physical performances and dyeing behaviour of silk fabrics
}

\author{
DOI: 10.35530/IT.071.04.1675
}

TUBA TOPRAK

PERVIN ANIS

MINE AKGUN

\author{
ABSTRACT - REZUMAT
}

\section{Effects of environmentally friendly degumming methods on some surface properties, physical performances and dyeing behaviour of silk fabrics}

In this paper, the effect of degumming processes on the physical performance, surface properties and colour coordinates of silk fabrics at high temperature and enzymatically, which was developed as an alternative to conventional method, has been investigated. Degummed silk fabrics were compared in terms of weight loss, bending length, tear and breaking strength, surface roughness and friction coefficient. After these tests, acid dyeing was performed to observe different degumming methods effect on dyeing behaviour of degummed silk fabric. The colour coordinates were evaluated by $L^{*}, a^{*}, b^{*}, C^{*}, h^{0}, K / S$, and $\Delta E^{*}$ values. The results revealed that despite insignificant differences between conventional and alternative methods in terms of physical performance and surface properties, the conventional method gave slightly better results than the others. There were no significant differences in colour depth between the two processes. These reasons showed that the alternative method could be used instead of the traditional method and a more sustainable process has been designed.

Keywords: degumming, enzyme, environmentally friendly, friction, roughness, silk

Influența metodelor ecologice de degomare asupra unor proprietăți de suprafață, performanțe fizice și comportamentul la vopsire al țesăturilor din mătase

În această lucrare, a fost analizată influența proceselor de degomare la temperatură ridicată și prin procedeu enzimatic, realizate ca o alternativă la metoda convențională, asupra performanței fizice, proprietăților de suprafață și coordonatelor colorimetrice ale țesăturilor din mătase. Țesăturile din mătase degomate au fost comparate din punctul de vedere al pierderii de masă, lungimii de încovoire, rezistenței la sfâșiere și rupere, rugozității suprafeței și coeficientului de frecare. După aceste teste, a fost realizată vopsirea cu coloranți acizi, pentru a se observa influența diferitelor metode de degomare asupra comportamentului la vopsire al țesăturii din mătase degomată. Coordonatele colorimetrice au fost evaluate prin valorile $L^{*}, a^{*}, b^{*}, C^{*}, h^{0}, K / S$ și $\Delta E^{*}$. Rezultatele au relevat faptul că, în ciuda diferențelor nesemnificative dintre metodele convenționale și cele alternative în ceea ce privește performanța fizică și proprietățile de suprafață, metoda convențională a dat rezultate puțin mai bune decât celelalte. Nu au existat diferențe semnificative de intensitate a culorii între cele două procese. Aceste argumente au demonstrat că metoda alternativă ar putea fi utilizată în locul metodei tradiționale și a fost proiectat un proces mai sustenabil.

Cuvinte-cheie: degomare, enzimă, ecologic, frecare, rugozitate, mătase

\section{INTRODUCTION}

Because of its comfort, elegance, sensuousness, luster, glamour and excellent mechanical properties, silk fiber is called "Queen of Textiles" and has been used for 5000 years [1-6]. Although the annual production of silk fiber is not very high, it remains a special fiber used in high value textile products. Increasing demand for natural fibers to meet environmental and consumer demands will lead to an increase in the use of this fiber [7].

The silk fibers obtained from the silk worm and it consists of mainly sericin (20-30\%), fibroin (65-75\%). There is about $5 \%$ water, wax, pigments, sugars, and mineral salts in the silk fiber $[4,8]$. Sericin covers a pair of fibroin filaments and allows them to stay together [9-11]. Fibroin and sericin proteins differ from each other in amino acid percentages and configurations. The fibroin formed by amino acids with about $76 \%$ non-polar side groups surrounds by sericin which consist $75 \%$ amino acids with polar groups [4, 12-13]. Fibroin is a dense structure of B-sheet microcrystals, whereas sericin is an amorphous structure [3,14]. These differences in configuration and composition of the fibroin and sericin make it possible for fibroin to contribute to the strength and stiffness, while the sericin that holds the fibroin together makes it more water soluble than fibroin $[6,15-17]$. While sericin causes the fiber to become stiff and harsh, it also hinders luster and whiteness of the silk, and prevents penetration of solutions used in 
textile wet processes [18]. Therefore, sericin has to be removed to make silk fiber the ideal fiber for textile industry [9]. In the process of removing sericin from the fiber, degumming, sericin is hydrolyzed and the amide bonds in the protein molecules are broken down [15]. Degumming, which causes a 20-25\% reduction in the weight of the fiber $[3,19]$, can be carried out with water under high pressure [20], by boiling in a soap-alkaline [8, 21-22] or acidic mediums [23-25], or enzymatically [4, 17]. The magnetic field also was used for degumming by Valu [26]. The recommended method is to boil with soap in the presence of alkali, but the chemicals used make it nonenvironmentally friendly [21, 27-29].

The $-\mathrm{NH}_{2}$ and $-\mathrm{COOH}$ groups in the chemical structure of the silk fiber enable this fiber to be dyed with acid, basic, metal complex, mordant, natural, and reactive dyes. The interaction between the dyestuff and the silk fiber occurs with ionic or covalent bonds. The choice of dyes depends on the shade, brightness and fastness grade properties. Acid dyes are used mostly and they are easily absorbed into fibers and washing fastness is poor to moderate [19, 21, 30-32].

Finishing processes to impart various handling and performance properties gain to textile materials such as smoothness, stiffness, softness, crease recovery, dimensional stability, and strength can also be done to change the frictional resistance of fabrics. Friction resistance is influential on abrasion, wear resistance, degree of consolidation and shrinkage properties, especially the key of the fabrics. Friction properties are also important in determining roughness, smoothness and other surface characteristics. While friction studies have been carried out on metals in the past, non-metals, which are the elastomers, plastics, and fibers, friction characteristics have begun to be studied in detail, and even this century can be called the "renaissance of tribology". Friction, a surface phenomenon, has long been used for the objective measurement of surface smoothness. Although friction is a surface property, it is also influenced by the bulk property and therefore the changes in the friction are also sensitive to the type of yarn mechanical properties, fabric structure, finishing process and also the conditions used during testing [33].

In this study, weight loss, bending lengths, tear and breaking strengths of the silk fabrics have been investigated for the possibility of environmental degumming with using enzyme and high temperature conditions as alternatives to conventional degumming. Silk fabric handling is one of the most attractive features for customers. That's why surface characteristics were analysed via surface roughness and friction coefficients after degumming processes. Differences created by different degumming processes on the dyeing properties of silk fabrics have also been investigated.

\section{EXPERIMENTAL WORK}

Material

A fine-medium weight $\left(76 \mathrm{~g} / \mathrm{m}^{2}\right) 100 \%$ silk plain woven fabric was used. This raw silk fabric was provided by Bursa Ijpek. The fabric properties are shown in table 1.

Table 1

CONSTRUCTIONAL PROPERTIES OF SILK FABRIC SAMPLE

\begin{tabular}{|l|c|c|}
\hline \multicolumn{1}{|c|}{ Parameters } & Warp & Weft \\
\hline Yarn count $(\mathrm{Nm})$ & 151 & $151 / 2$ \\
\hline Yarn density (thread/cm) & 26 & 18 \\
\hline Yarn twist $(\mathrm{T} / \mathrm{m})$ & Non-twisted & 248 \\
\hline
\end{tabular}

The commercial acid dye (Lanaset Red 2B), wetting agent (Albaflow Jet) and leveling agent (Albegal) were kindly provided by Huntsman Cooperation, Turkey. Sodium sulfate, acetic acid, sodium bicarbonate and Marseilles soap were analytical reagent grades. Savinase 16L, protease (Novozymes), which was produced from Bacillus sp was used in enzymatic degumming processes.

\section{Method}

\section{Degumming and dyeing}

The degumming processes were grouped into three groups: boiling off with soap in alkaline medium, enzymatic degumming, and high temperature (HT) degumming. Marseilles soap was used in the conventional process based on comparing the effectiveness of the other degumming processes. Silk fabrics were treated conventionally with $3.5 \mathrm{~g} / \mathrm{l}$ Marseille soap, $2.5 \mathrm{~g} / \mathrm{l}$ sodium bicarbonate $(\mathrm{pH} 9.5)$ at $95^{\circ} \mathrm{C}$ for 45 min with an LR value of $25: 1$. For degumming with enzymes in all experiments $8 \%$ enzyme was used in $\mathrm{pH} 8.5$ medium which was adjusted with sodium bicarbonate and was recommended by Novozymes. The conditions of the enzymatic degumming were $50^{\circ} \mathrm{C}$ for 20 min (LR 25:1). The HT degumming processes were operated at the $110^{\circ} \mathrm{C}$ for 20 and 30 minutes and named as HT 20' and HT 30', respectively. For enzymatic and conventionally degummed fabrics, neutralization process was operated with acetic acid. Finally, all degummed fabrics were rinsed water at $70^{\circ} \mathrm{C}$ for 10 minutes two times.

The woven silk fabrics were dyed using exhausting method under laboratory conditions. In the dyeing experiments, the fabric samples weighed $10 \mathrm{~g}$ and the liquor ratio was $25: 1$. The dyebaths contained $2 \%$ owf (on-weight-fabric) acid dye, $1 \mathrm{~g} / \mathrm{l}$ penetration agent, $5 \%$ owf sodium sulphate, and $1 \%$ owf acetic acid. In the dyeing bath at $40-50^{\circ} \mathrm{C}$ containing acetic acid and sodium sulphate fabric was treated for ten minutes. Then, acid dye was put into the bath and the temperature was raised to $80-85^{\circ} \mathrm{C}$ at a rate of $1^{\circ} \mathrm{C} /$ minute. The dyeing was continued at this temperature for 60 minutes to allow good penetration of the dyes and level dyeing. Later the samples were 
taken out of the dyeing tubes and were rinsed with hot $\left(70^{\circ} \mathrm{C}\right)$ and cold water $\left(30^{\circ} \mathrm{C}\right)$ for 10 minutes, respectively. After rinsing the samples were left to dry under laboratory conditions.

The degumming processes were performed with ATAÇ Dyetech Sample Dyeing Machine and the ATAÇ Mini Bobbin Dyeing Machine (MBB01-02F). For dyeing process, ATAÇ Dyetech Sample Dyeing Machine was used. The raw silk fabric was used without further treatment for all experiments for comparison. Each experiment was performed by nondyed silk fabric at three times.

The effects of degumming methods and dyeing were analysed with the following tests.

\section{Bending length}

Bending lengths of fabrics were measured according to "Standard Test Method for Stiffness of Fabrics ASTM D 1388-96" test method by SDL ATLAS Fabric Stiffness Tester M003B.

\section{Tear strength}

The Power Tear (SDL ATLAS M008HE) was used to measure the tear strengths according to "TextilesTear properties of fabrics - Part 1: Determination of tear force using ballistic pendulum method (Elmendorf) (TS EN ISO 13937-1:2000)".

\section{Breaking strength}

The Shimadzu AG-X plus was used for measuring the breaking strengths of the fabric via ASTMD 1682-64. Surface roughness test

Surface roughness values of silk samples were measured by a roughness tester (Accretech Surfcom $130 \mathrm{~A}$ ) and surface roughness values were recorded according to ISO 4287-1997. The measurement was performed on steady state without causing any further tension on the sample. Three roughness measurements were made on each direction (warp and weft) with the selected measurement parameters of $50 \mathrm{~mm}$ evaluation length ( $0.8 \mathrm{~mm}$ cut-off value) and $1.5 \mathrm{~mm} / \mathrm{s}$ measurement speed. Three measurements were recorded in each directions and the mean was calculated.

$R_{a}$ is the arithmetical average of absolute values of the profile variations (peaks and valleys) from the mean line in the evaluation length [34-36]. This value was calculated using equation 1 :

$$
R_{a}=\frac{1}{n} \sum_{i=1}^{n}\left|y_{i}\right|
$$

where $n$ is the number of samples along the evaluation length and $y_{i}$ - (surface height) deviation.

\section{Friction coefficient test}

The static and kinetic friction coefficients used to evaluate the friction characteristics of the fabrics were measured according to ASTM D 1894-14: 2014 standard on a Labthink Param MXD-02 friction coefficient test device.

Static and kinetic friction coefficients of the silk fabric were measured by fabric-to-fabric friction by using standard abrasive wool fabric (ASTM D 4966) (i.e. friction coefficients of sample were measured by silk fabric-to-abrasive wool fabric). The silk fabric sample under test was mounted on the sled (mass of sled: $200 \mathrm{~g}$ ) and standard abrasive wool fabric was mounted on the moving plate (the test speed: $150 \mathrm{~mm} / \mathrm{min}$; the measurement length: $150 \mathrm{~mm}$ ) of the coefficient tester. Friction measurements were performed in warp and weft directions of fabric samples under test. Three measurements were recorded in each directions and the mean was calculated.

\section{Colour measurement}

The colour coordinates of samples were measured by Konika - Minolta 3600D reflectance spectrophotometer coupled to a $\mathrm{PC}$, at wavelengths between 400 and $700 \mathrm{~nm}$ under D $65 / 10^{\circ}$ illuminant with specular component included ( $\mathrm{SCl}$ mode). The percentage reflectance values at the wavelength of maximum absorption (500 nm) were recorded. The conventionally treated fabrics were taken as the standards and the other fabrics were taken as the samples when calculating the colour differences. CIELAB (1976) equation 2 was used to calculate colour differences:

$$
\Delta E_{C I E L A B}^{*}=\sqrt[2]{\left(\Delta L^{*}\right)^{2}+\left(\Delta a^{*}\right)^{2}+\left(\Delta b^{*}\right)^{2}}
$$

where $\Delta L^{*}$ is the lightness difference, $\Delta a^{*}$ - red/green difference, $\Delta b^{*}$ - yellow/blue difference.

The $K / S$ value was calculated for the wavelength corresponding to the maximum absorption value. The $\Delta E^{*}$ was calculated according to CIELAB 1976 equation 3:

$$
K / S=\frac{(1-R)^{2}}{2 R}
$$

where $R$ is the decimal fraction of the reflectance of fabric, $K-$ the absorption coefficient, $S$ - the scattering coefficient.

\section{RESULTS AND DISCUSSION}

\section{Weight loss}

Figure 1 shows the average weights of the fabrics after different degumming methods.

The lowest weight was obtained by conventional method. It was worth noting that this process showed a very high degumming efficiency. The conventional process caused about $25 \%$ weight losses indicated the target value for complete degumming, as obtained under standard conditions with soap and alkali. Without enzymes, the HT 30' degumming process loss was very close to the conventional treatment and differences between them was negligible

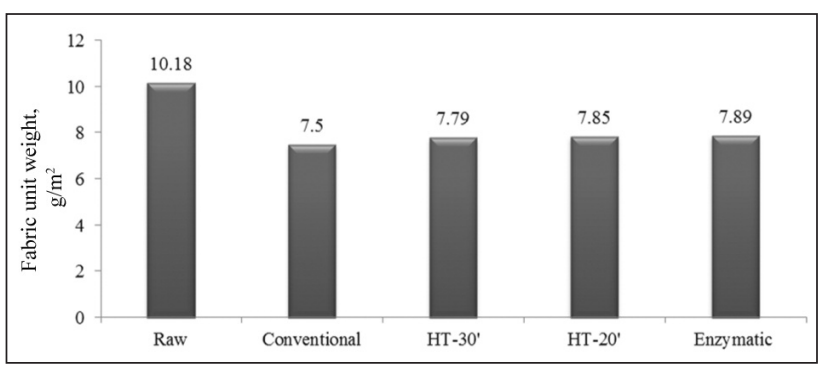

Fig. 1. Weights of silk fabrics after different degumming processes 
$(\approx 5 \%)$, owing to the highest treatment temperature. Compared to HT 30', the HT 20' caused almost 5\% less weight loss because the time was less than 10 minutes. Degumming loss with enzyme was approximately same with the HT 20' process. The protease enzyme used in this study allowed a $10 \%$ difference to the targeted loss of weight $(\approx 25 \%)$ under the adopted experimental conditions.

\section{Bending length}

The bending length values, one of the performance characteristics, are shown in figure 2.

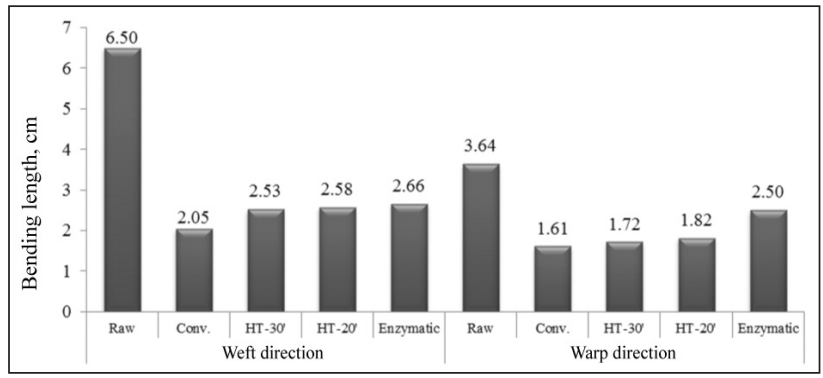

Fig. 2. Bending length values of silk fabrics after different degumming processes

The silk fabrics degummed with conventional method showed the lowest bending lengths since the sericin which gives the fabric hardness was removed at the maximum amount. There were no significant differences between these values for HT 20' and HT 30'. The bending length values obtained by the enzymatic process were slightly higher because the enzymatic process removed the sericin less than HT 20'HT 30' and the conventional methods, whereas the success of this method was significantly prominent when compared with the raw fabric. Moreover, this result indicated that enzymatic degummed fabric structure was harder than the others, except raw. By comparing the fabrics degummed with the conventional and environmentally friendly methods, it was possible to observe that the latter exhibited a bit harder fabrics, especially enzymatically treated one. These results were parallel to the weight loss values of the fabrics, and the fabrics exhibited the greatest and least weight loss gave the lowest and the highest bending lengths, respectively. This could be interpreted as the fabric became softer when sericin moved away from the fabric, thus reducing the bending length of the fabric because sericin gives the fabric rigidity.

\section{Tear strength}

The main effect of degumming processes for fabric tear strengths are given in figure 3 .

It could be seen that the starting with tear strength of the raw silk fabric $(43.19 \mathrm{~N})$ for weft direction, it increased after degumming processes. This increase in tear strength could be explained by removing the sericin which prevents the ability of the yarns to move together against the tear force applied to the fabric. When the degumming processes were compared

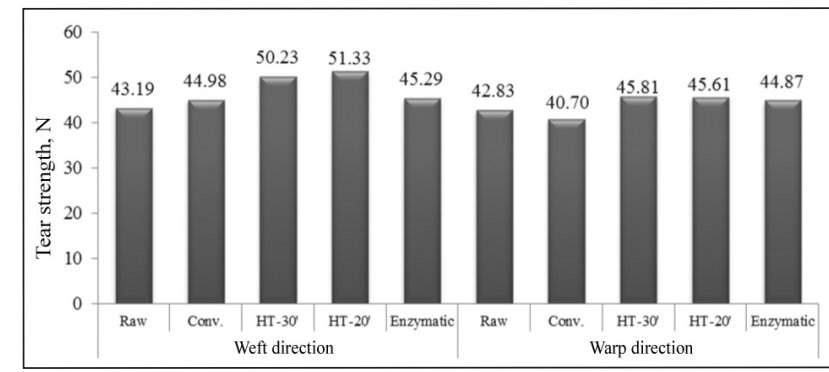

Fig. 3. Tear strengths of degummed silk fabrics with various degumming processes

with each other, the lowest results were obtained with the conventional process. The possible reason for the highest tear strength loss was not only the sericin in the amorphous structure but also the fibroin structure in the crystalline structure was damaged in the conventional degumming process which operated under alkaline conditions [1]. The HT 20' and HT 30' conditions gave higher tear strength values in the weft direction than the enzymatic process. It could be seen that ten minutes difference between the HT processes did not cause any significant change in the tear strength values both of the direction. When effects of degumming processes on the tear strength values at the weft and warp directions were compared to the raw fabrics, the differences in the weft direction were more pronounced, which was thought to have stemmed from the two-ply weft yarn.

\section{Breaking strength}

The effect of degumming processes under investigation could be realized by comparing the breaking strength, which was one of the physical properties of the fabric, is shown figure 4.

Based on breaking strength, the raw silk fabrics had the highest strength, implied that the sericin reinforced to the fabric, so the removing sericin with various degumming methods led to a decrease in the breaking strength. This reduction was the most in conventional process as expected because the sericin was removed at the most amount in the conventional process (figure 1). Another possible reason for this loss was the conventional process conditions caused fiber degradation [1]. When HT 20', HT 30',

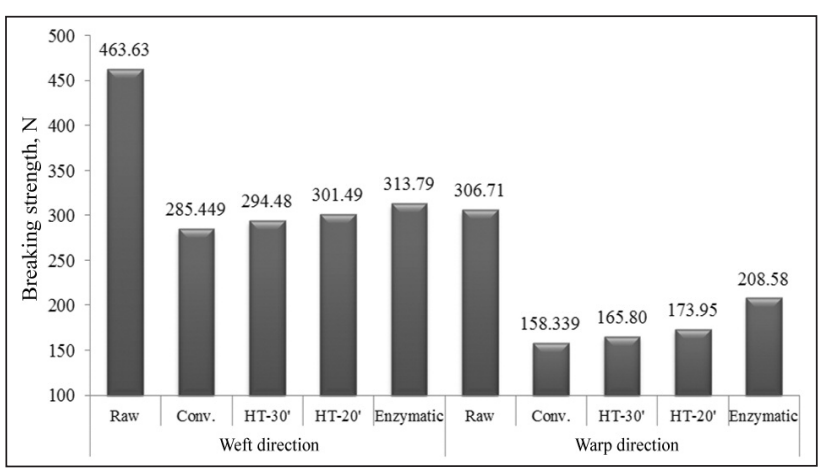

Fig. 4. Breaking strengths of degummed silk fabrics 
and enzymatic degumming processes were compared among themselves, it was seen that the HT processes had lower breaking strength values. It had also turned out that the difference in the process times of HT processes did not cause any significant change $(\approx 2-4 \%)$. Since the working conditions in the enzymatic process were milder and the amount of sericin removed from the fiber by this process was less, so the least strength loss was seen in this method. Although this loss was the least in the enzymatic process compared to other degumming processes, the loss of strength was about $32 \%$ compared to the raw silk fabric. Since two-ply yarn was used in the weft direction, it was seen that the strength of this direction was higher than the warp direction.

\section{Surface roughness}

In figure 5, the changes in the surface roughness values of the weft and warp directions of the silk fabrics, in accordance with the different sericin removing methods, are presented.

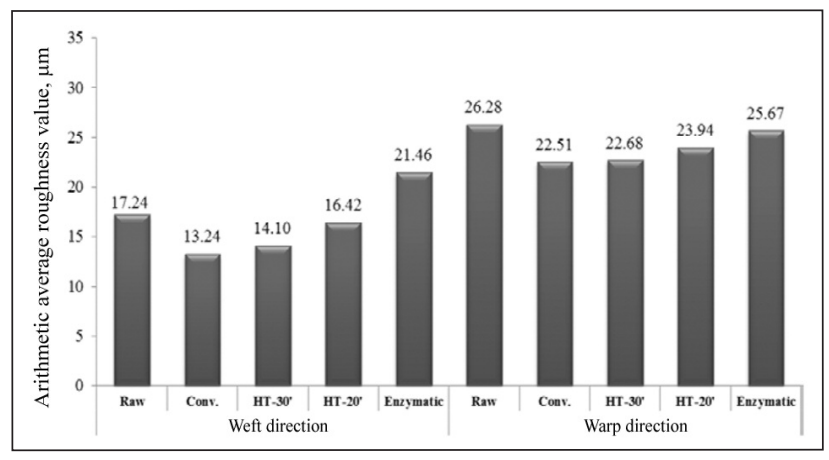

Fig. 5. Surface roughness values of silk fabrics with various degumming processes

In order to evaluate the effect of sericin on the surface roughness, it was observed that the raw fabric had a higher surface roughness compared to the conventionally degumming method by which the sericin was removed at the maximum amount through the fabric. In the conventional method, it was considered that the sericin-removed fibroin has a smoother surface because of its lower results. It was thought that higher values were obtained in the enzymatic process than other degumming methods because the sericin on the surface cannot be removed completely and properly. The surface roughness results at $\mathrm{HT}$ processes were lower than the enzymatic process and but they were higher than the conventional process. The data of HT 30' indicated that sericin was more uniformly removed from the surface than HT 20'. In general, these results showed that sericin increased the surface roughness of the fabrics, that is, all degumming processes made the surface of the fabrics smoother.

For all processes, when the weft and warp direction roughness values were compared, it was observed that the higher results were obtained in the warp direction. This could stem from differences in the density and count of warp and weft yarns. During the measurement of the roughness in the warp direction, the stylus probe of the roughness measurement device moves on the cross direction on each of the thread spacing of individual weft yarns in the fabric structure. Taking into consideration that the weft yarn density constituting the fabric were lower than the warp yarn density, this state caused higher thread spacing of individual weft yarns, as a result the roughness values of fabrics obtained from the warp direction were determined to be higher than the roughness values of fabrics obtained from the weft direction. An increase in yarn density decreased the gaps between the yarn peaks, giving a decrease in surface roughness [35-36]. Also, the coarse structure of weft yarn (weft yarn thickness two times higher than the warp yarn) could have led to a higher yarn peaks on the surface during the measurement of the roughness in the warp direction, and as a result the fabric surface roughness increased in the warp direction.

\section{Friction coefficients}

In figure 6, the changes in the friction coefficient values of the weft and warp directions of the silk fabrics, in accordance with the different sericin removing methods, are presented. The raw fabric gave the lowest friction coefficient values in both directions and these values increased after degumming processes. Sericin in raw silk fabric provided low friction coefficient values because it made fabric structure stiffer and it had not adhesive feature which occurs by fabric-to-fabric friction. After the degumming process, it was observed that this process made the silk fabric feel smoothly handle and increased potential of the fabric to stick or cling to the other surfaces. As a result of this, the friction coefficient values of silk fabrics increased after degumming processes. When the degumming processes were compared in both directions, it was observed that the friction coefficient values were almost close to each other in the warp direction, but the values of the friction coefficients were slightly more pronounced in in the weft direction. When the differences between the degumming processes in the weft direction were analysed, it was seen that the amount of sericin left on the fabric surface was related to the friction coefficient. It could be

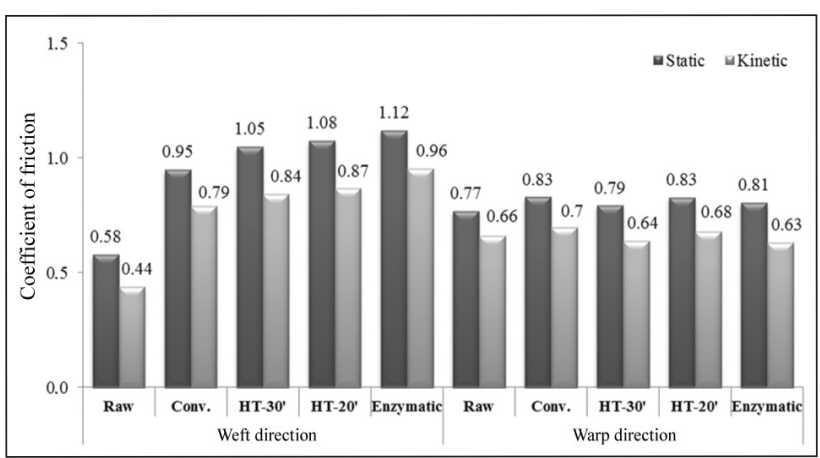

Fig. 6. Friction coefficient values of silk fabrics with various degumming processes 


\begin{tabular}{|c|c|c|c|c|c|c|c|}
\hline \multicolumn{7}{|c|}{ COLOUR COORDINATES OF SILK FABRICS WITH VARIOUS DEGUMMING PROCESSES } \\
\hline Process & $\mathbf{L}^{*}$ & $\mathbf{a}^{*}$ & $\mathbf{b}^{*}$ & $\mathbf{C}^{*}$ & $\mathbf{h}^{\mathbf{*}}$ & \multicolumn{1}{|c|}{ K/S } & $\Delta \mathbf{E}^{*}$ \\
\hline HT20' & 49.10 & 50.25 & 17.32 & 52.98 & 19.01 & 8.20 & 0.53 \\
\hline HT30' & 49.28 & 50.39 & 17.47 & 53.27 & 18.79 & 8.24 & 0.46 \\
\hline Enz. & 48.75 & 50.10 & 17.05 & 52.92 & 19.11 & 8.48 & 0.84 \\
\hline Conv. & 49.42 & 50.60 & 17.09 & 53.41 & 18.66 & 8.68 & - \\
\hline
\end{tabular}

interpreted that the remaining sericin on the surface enhanced the irregularity, which in turn increased the friction coefficient.

\section{Colour coordinates}

The colorimetric coordinates $\left(L^{*}, a^{*}, b^{*}, C^{*}, h^{\circ}\right), K / S$, and $\Delta \mathrm{E}^{*}$ values of all the dyed fabrics are given in table 2.

The $L^{*}$ values given in table 2 revealed that the enzymatic degummed fabrics had the lowest $L^{*}$ values, i.e. darker than the others. However, it seemed that the difference between these values and others was not very high. In table 2 , it could be seen that the values of $a^{*}$ (redness) were higher than those of $b^{*}$ (blueness) as expected because red dyestuff was used. The $a^{*}, b^{*}, C^{*}$ and $h^{\circ}$ values for each process were very close to each other. It was also observed from the $\Delta \mathrm{E}^{*}$ values that the differences between them were negligible $(<1)$. The differences between them were less than 1 could be interpreted as each could be used as an alternative process. Moreover, this was expected because the removed sericin amounts of alternative processes were about the same. Colour strength (K/S), which was the most important parameter to test the quality measurement of a sample in terms of depth of the colour, showed similar results to each other. Additionally, with the help of alternative methods, levelled dyeing could be achieved.

\section{CONCLUSIONS}

In this study, the effects of different degumming processes applied to $100 \%$ silk woven fabric on the mechanical properties (weight loss, bending length, tear strength, breaking strength), surface properties (roughness and friction coefficient) and colour coordinates $\left(L^{*}, a^{*}, b^{*}, C^{*}, h^{\circ}, K / S\right.$ and $\left.\Delta E^{*}\right)$.

According to the results, despite the sericin was removed at the most amount by conventional method (as seen from the changes in the weight loss and bending length values), it had been found that the other alternative methods (HT and enzymatic) gave similar values to those obtained from the conventional process. When the effect on the fabric strength values (tear and breaking strength) of the different degumming processes were examined, it was seen that the most loss of strength was seen in the fabric treated with conventionally where the sericin was removed the most amount. The breaking strength values of the enzymatically treated fabrics were highest.

When the effects of different degumming treatments on the fabric surface properties (roughness and friction coefficient) were examined, it was seen that the lowest surface roughness values were obtained by the conventional process. With the enzymatic process, roughness values were high because of the sericin remaining on the surface of fiber. When the friction coefficient values were examined, it was observed that the coefficient of surface friction of the sericin-free fabric was increased. This was due to the sticking or clinging effect between the sericin and the other surface it touches, due to the softer handling of the degummed fabric. It had been observed that the different sericin removal processes gave nearly similar results on the fabric friction coefficients.

After different degumming processes, the silk fabric colour coordinates $\left(\mathrm{L}^{*}, \mathrm{a}^{*}, \mathrm{~b}^{*}, \mathrm{C}^{*}, \mathrm{~h}^{\circ}, \mathrm{K} / \mathrm{S}\right.$ and $\left.\Delta \mathrm{E}^{*}\right)$ showed that the results obtained with degumming processes results were similar to each other. Although the highest colour difference value was 0.84 between conventional and enzymatic degumming, this difference value was also insignificant because it was below 1 .

As a result, it had been observed that degumming processes with alternative methods had no negative effects on the physical and surface properties of silk fabrics. The colour coordinates and uniform dyeing obtained by the dyeing after the application of these methods to silk fabrics showed they could be alternatively used. Furthermore, other advantages of environmentally degumming processes were the lack of chemical usage and short processing times.

\section{REFERENCES}

[1] Padaki, N.V., Das, B., Basu, A., Advances in understanding the properties of silk, In: Basu, A., editor. Adv. Silk Sci. Technol., Amsterdam: Elsevier Ltd., 2015, 1-16, https://doi.org/10.1016/B978-1-78242-311-9.00001-X

[2] Dash, B.C., Mandal, B.B., Kundu, S.C., Silk Gland Sericin Protein Membranes: Fabrication and Characterization for Potential Biotechnological Applications, In: J. Biotechnol., 2009, 144, 321-329, https://doi.org/10.1016/ j.jbiotec.2009.09.019 
[3] Mahmoodi, N.M., Moghimi, F., Arami, M., Mazaheri, F., Silk Degumming Using Microwave Irradiation as an Environmentally Friendly Surface Modification Method, In: Fibers Polym., 2010, 11, 234-240, https://doi.org/ 10.1007/s12221-010-0234-2

[4] Arami, M., Rahimi, S., Mivehie, L., Mazaheri, F., Mahmoodi, N., Degumming of Persian Silk with mixed Proteolytic Enzymes., In: J. Appl. Polym. Sci., 2007, 106, 267-275, https://doi.org/10.1002/app.26492

[5] Rippon, J.A., Evans, D.J., Improving the Properties of Natural Fibres by Chemical Treatments, In: Kozlowski, R., editor. Handb. Nat. Fibres, Woodhead Publishing Limited, 2012, 63-140, https://doi.org/10.1533/ 9780857095510.1 .63

[6] Asakura, T., Kaplan, D.L., Silk Production and Processing, In: Arutzen, C.J., editor. Encycl. Agric. Sci., New York: Academic Press, 1994, 1-11

[7] Shen, J., Enzymatic Treatment of Wool and Silk Fibres, In: Nierstrasz, V.A., Cavaco-Paulo, A., editors. Adv. Text. Biotechnol., Cambridge: Woodhead Publishing, 2010, 171-192, https://doi.org/10.1533/9780857090232.2.171.

[8] Cao, T.T., Wang, Y.J., Zhang, Y.Q., Effect of Strongly Alkaline Electrolyzed Water on Silk Degumming and the Physical Properties of the Fibroin Fiber, In: PLoS One, 2013, 8, e65654, https://doi.org/10.1371/journal.pone. 0065654

[9] Mossotti, R., Innocenti, R., Zoccola, M., Anghileri, A., Freddi, G., The Degumming of Silk Fabrics: A Preliminary Near Infrared Spectroscopy Study, In: J. Near. Infrared Spectrosc., 2006, 14, 201-208

[10] Magoshi, J., Magoshi, Y., Becker, M.A., Nakamura, S., Biospinning (silk fiber formation, multiple spinning mechanisms), In: Salamone, J.C., editor. Polym. Mater. Encycl., New York: CRC Press, 1996, 132-133

[11] Gulrajani, M.L., Purwar, R., Prasad, R.K., Joshi, M., Studies on Structural and Functional Properties of Sericin Recovered from Silk Degumming Liquor by Membrane Technology, J. Appl. Polym. Sci., 2009, 113, 2796-2804, https://doi.org/10.1002/app

[12] Trotman, E.R., Animal Fibres, In: Trotman, E.R., editor. Dye. Chem. Technol. Text. Fiber. 4th ed., London: Charles Griffin \& Co., 1970, 74-108, https://doi.org/10.1533/9781855738973

[13] Zhang, Y.Q., Applications of Natural Silk Protein Sericin in Biomaterials, Biotechnol. Adv., 2002, 20, 91-100

[14] Takahashi, Y., Gehoh, M., Yuzuriha, K., Crystal Structure of Silk (Bombyx mori), J. Polym. Sci., 1991, 29, 889-891

[15] Chopra, S., Gulrajani, M.L., Comparative Evaluation of the Various Methods of Degumming Silk, Indian J. Fibre Text. Res., 1994, 19, 76-83

[16] Jiang, P., Liu, H., Wang, C., Wu, L., Huang, J., Guo, C., Tensile Behavior and Morphology of Differently Degummed Silkworm (Bombyx mori) Cocoon Silk Fibres, Mater. Lett., 2006, 60, 919-925 https://doi.org/10.1016/ j.matlet.2005.10.056

[17] Freddi, G., Mossotti, R., Innocenti, R., Degumming of Silk Fabric with Several Proteases, J. Biotechnol., 2003, 106, 101-112, https://doi.org/10.1016/j.jbiotec.2003.09.006

[18] Haggag, K., El-Sayed, H., Allam, O.G., Degumming of Silk Using Microwave-Assisted Treatments, J. Nat. Fibers, 2007, 4, 1-22, https://doi.org/10.1300/J395v04n03

[19] Teli, M.D., Advances in the Dyeing and Printing of Silk. In: Basu, A., editor. Adv. Silk Sci. Technol., AMSTERDAM: Elsevier Ltd., 2015, 55-78, https://doi.org/10.1016/B978-1-78242-311-9.00004-5

[20] Zhang, Y.Q., Shen, W.D., Tao, M.L., Zhou, W.L., Ma, Y., Ding, Y., Production Method of Water Soluble Sericin, CN 1477141A, 2004

[21] Shukla, S.R., Manisha, R.M., Low-temperature Ultrasonic Dyeing of Silk, In: Color Technol., 1995, 111, 342-345

[22] Gowda, K.N., Padaki, N.V., Sudhakar, R., Subramani, R., Eco-friendly Preparatory Process for Silk: Degumming by Protease Enzyme, In: Man-Made Text. India, 2007, 50, 28-31

[23] Gulrajani, M.L., Chatterjee, A., Degumming of Silk with Oxalic Acid, In: Indian J. Fibre Text. Res., 1992, 17, 39-44, https://doi.org/10.1111/j.1478-4408.1992.tb00091.x

[24] Gulrajani, M.L., Sethi, S., Gupta, S., Some Studies in Degurnming of Silk with Organic Acids, In: J. Soc. Dye Colour, 1992, 108, 79-86

[25] Khan, M.M.R., Tsukada, M., Gotoh, Y., Morikawa, H., Freddi, G., Shiozaki, H., Physical Properties and Dyeability of Silk Fibers Degummed with Citric Acid, In: Bioresour. Technol., 2010, 101, 8439-8445, https://doi.org/10.1016/ j.biortech.2010.05.100

[26] Valu, F., Homutesko, J., Degumming of Silk in Presence of Magnetic Field for Reduced Degradation, In: Chem. Abstr., 1984, 100, 157-158

[27] Vaithanomsat, P., Kitpreechavanich, V., Sericin Separation from Silk Degumming Wastewater, In: Sep. Purif. Technol., 2008, 59, 129-133, https://doi.org/10.1016/j.seppur.2007.05.039

[28] Gulrajani, M.L., Das, S., Sethi, S., Degumming of Murshidabad Silk Fabrics with Alkalies, In: Indian J. Fibre Text. Res., 1990, 15, 173-179

[29] Fabiani, C., Pizzichini, M., Spadoni, M., Zeddita, G., Treatment of Waste Water from Silk Degumming Processes for Protein Recovery and Water Reuse, In: Desalination, 1996, 105, 1-9, https://doi.org/10.1016/00119164(96)00050-1

[30] Chakraborty, J.N., Dyeing of Silk, In: Chakraborty, J.N., editor. Fundam. Pract. Colouration Text., Cambridge: Woodhead Publishing, 2010, 214-221, https://doi.org/10.1533/9780857092823

[31] Work, R.W., The Force-Elongation Behavior of Web Fibers and Silks Forcibly Obtained from Orb-Web-Spinning Spiders, In: Text. Res. J., 1976, 46, 485-492

[32] Babu, K.M., The Dyeing of Silk. In: Babu KM, editor. Silk Process, In: Prop. Appl., Oxford: Woodhead Publishing, 2013, 117-139, https://doi.org/10.1533/9781782421580.117

[33] Gupta, B.S., Textile fiber morphology, structure and properties in relation to friction, In: Gupta, B.S, editor. Frict. Text. Mater., Cambridge: Woodhead Publishing, 2008, 3-36, https://doi.org/10.1533/9781845694722.1.3 
[34] Gadelmawla, E.S., Koura, M.M., Maksoud, T.M.A., Elewa, I.M., Soliman, H.H, Roughness Parameters, In: J. Mater. Process. Technol., 2002, 123, 133-145, https://doi.org/10.1016/S0924-0136(02)00060-2

[35] Akgun, M., Assessment of the Surface Roughness of Cotton Fabrics Through Different Yarn and Fabric Structural Properties, In: Fibers Polym., 2014, 15, 405-413, https://doi.org/10.1007/s12221-014-0405-7

[36] Akgun, M., Assessment of the Effect of Fabric Constructional Parameters on Surface Roughness of Wool Fabrics, In: J. Text. Inst., 2015, 106, 845-852, https://doi.org/10.1080/00405000.2014.948730

\section{Authors:}

TUBA TOPRAK, MINE AKGUN, PERVIN ANIS

Bursa Uludag University, Faculty of Engineering, Textile Engineering Department, Gorukle Campus,

16059, Nilufer, Bursa, Turkey

e-mail: akgunm@uludag.edu.tr, pervin@uludag.edu.tr

Corresponding author:

TUBA TOPRAK

e-mail: tubatoprak@uludag.edu.tr 